\title{
NIH to abandon young investigator grants
}

[WASHINGTON] Senior officials at the US National Institutes of Health (NIH) last week decided to end a special category of grants restricted to new investigators. From next year, all new grant applicants will compete in the larger, more competitive pool for standard grants.

But by committing itself to maintaining the total number of new NIH investigators - 1,466 new investigators entered the NIH system in 1997, about one-third on new investigator grants (see figure) - the NIH has effectively promised to deliver up to $\$ 300$ million more in total grant funding in the year five years hence, when the last of the much less costly grants for new investigators expire.

"This is a really important signal about how strongly the institutes and [NIH director Harold] Varmus feel about the support of new investigators," says Wendy Baldwin, the deputy director of NIH's Office of Extramural Research. "This is going to cost us."

She adds that the change will modify a funding system that has inadvertently created a second class of financially constrained investigators. "We don't want two classes of new investigators. We want people to size their grants appropriate to the work they are proposing to do."

The grants to be phased out are called R29s, or 'First Independent Research Support and Transition' (FIRST) awards. They were established in 1987 to help new investigators make the transition from postdoctorate to independent investigator, and provide $\$ 350,000$ in direct money over five years, or $\$ 70,000$ a year.

About one-third of new investigators enter the NIH system on these grants. The

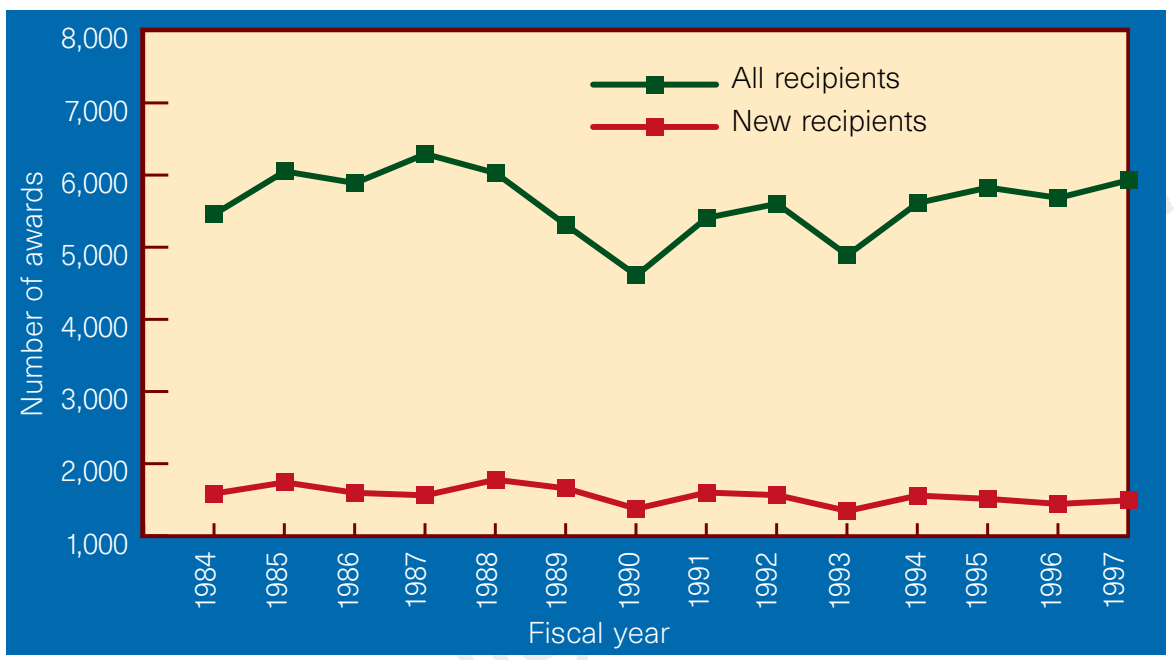

Recipients of NIH competing research project grants (R01 and R29), 1984-97.

Source: NIH

others enter directly into competition for standard R01 grants, which deliver on average $\$ 138,000$ a year in direct costs — about twice as much as the R29s.

At a meeting last Thursday (13 November), the heads of NIH's institutes voted unanimously to adopt a recommendation proposed last spring by an NIH working group on new investigators. This concluded that the small size of R29s was hampering young researchers more than access to a less competitive applicant pool was helping them (see Nature 387, 835; 1997).

The working group pointed out, for instance, that new investigators who were awarded R29s (except for those in the top 10 percentile) were significantly less successful - 6 to 8 per cent - in getting future grants than new investigators who entered the NIH

\section{Mixed experience with R29 'baby grants'}

[WASHINGTON] The US National Institutes of Health $(\mathrm{NIH})$ working group that reported last spring (see above) found a common complaint among R29 recipients it interviewed: funds were so paltry that they were forced to spent large amounts of time writing applications for other grants to meet their laboratory costs.

Jais Lingappa, 38, a cell biologist at the University of California, San Francisco, calls her R29 funding "untenable". She says that $\$ 70,000$ a year "barely covers my salary plus a small amount for equipment, and is not enough to hire anybody else to work with me".
As a result, says Lingappa, who landed her R29 this year, she is now considering applying for an R01 and giving up the smaller grant. "I certainly wish that [the $\mathrm{NIH}$ decision] had been instituted earlier."

Anecdotal evidence also suggests that those awarded R29s have been

handicapped by the perception that they are 'baby grants' without the prestige of R01s. David Kupfer, chairman of psychiatry at the University of Pittsburgh School of Medicine, says that he used to encourage young scientists to apply for R29s.
But he stopped after watching a tenure committee deny a young neuroscientist partly because of the "stigma" of his R29 grant.

But others have had a different experience. George Prendergast, a 36-year-old molecular geneticist at the Wistar Institute in Philadelphia, was recently promoted to associate professor. Since receiving an R29 grant three years ago, he has applied for and received an additional \$1.1 million in funding from other organizations for his cancer research laboratory. "It certainly hasn't held us back," he says.

M.W. system on R01s.

Under the new policy, existing R29s will be funded throughout their current lives. But from next June, NIH will no longer accept R29 applications.

New investigators will apply for standard grants, with their applications flagged as coming from first-time applicants, and reviewers will be asked to "give new investigators a break", says Marvin Cassman, director of the National Institute of General Medical Sciences, who co-chaired the working group. For instance, new applicants will be granted "some leeway" in terms of preliminary data: "We want reviewers to give the same benefits to the new R01 applicants that they gave to the R29 applicants," Cassman says.

Baldwin says that she and Elvera Ehrenfeld, director of NIH's Center for Scientific Review (formerly the Division of Research Grants) will work with reviewers this winter to determine the best way for applications to be flagged. Something as simple as a stamp on the front could suffice for now, she says. The actual application form cannot be changed overnight — government procedures will prevent that happening for 18 months.

"Although the R29 certainly sounded like a good idea it just didn't work out all that well," says Cassman. "You can't conduct a reasonable research program on $\$ 70,000$."

$\mathrm{NIH}$ officials say that the extra $\$ 300$ million required to fund today's number of new investigators on more generous standard grants is a rough estimate that assumes that the costs of R01 projects proposed by new investigators will match those in the overall pool. It could be less if new applicants as a group come in with more modest grant proposals. But the number incorporates a commitment to maintaining an influx of new investigators sufficient to replace the annual 8-9 per cent attrition rate among principal investigators.

MeredithWadman 